Marek Stefański*

\title{
Transformation of the Polish Banking Sector
}

\begin{abstract}
Summary
In the post-war period the banking system in Poland underwent two important system transitions: after 1946 and after 1989. The third transformation began after May 1, 2004, but it did not have a systemic character. The Polish banking sector started to operate on the Single European Market. The first part of the paper is devoted to the problems of the banks' transformations after 1989 with a special focus on the quantitative development of banks in 1989-2008, and on subsequent privatisation and consolidation processes. The former intensified in 1989-1999, and the latter in 1999-2002. The consolidation process was very noticeable in the sector of cooperative banks after 1994. The second part of the paper includes an economic and financial analysis of the banks. A lot of attention was paid to the liquidity of the banking sector. It was assessed as good, which was confirmed by a short-term rating of Moody's and by the Financial Stability Report 2009, published by the National Bank of Poland in June 2009. The comparison of the net profit of the banking sector in 1997-2008 shows its dependence on the economic situation and policy. The number of banks with capital adequacy ratio well above the minimum required by the banking supervision is rising. The financial power ratings are not favorable for the domestic banks. The third part of the paper focuses on the development directions of the Polish banking sector. It may be concluded on the basis of the analysis that privatisation and consolidation processes will be continued. They will concentrate on the capital of foreign banks already operating in Poland. As compared with individual foreign banks, the potential of the Polish banking sector is week. The fourth part of the paper focuses on the presentation Polish banking sector in the context of European Union banking sector. The paper finishes with conclusions. Generally, Polish banks have to implement a strategy to enable them to compete on the Single European Market, i.e. to look for new revenue
\end{abstract}

${ }^{*}$ Dr, University of Human Science and Economy in Wloclawek, Poland. 
sources, to reduce costs and improve their loan portfolios. The comparison of selected aspects of the Polish banking sector in the most developed EU Member States shows that the differences are still too large. Therefore, it seems correct to claim that the Polish banking system is undergoing another transition. It is adjustment to the Single European Market.

\section{Introduction}

Main target of the paper is presentation selected aspects the Polish banking sector in the transition period (1989-2008). Banking system composes banks (created banking sector) and external institutions relatively to them (Zaleska, 2007). The most important external institutions are: central bank, supervision of banking market, guarantee deposit system. The article focuses on analysis of banking sector, which present functioning banks (commercial and cooperative). Author makes economic and financial analysis of the banking sector and present changes in banking law. His study should answer for following questions: Is Polish banking sector stable? Do Polish banks act in accordance with the principle of an open market economy with free competition on the Single European Market? What is the position of the Polish banking sector in the European Union?

\section{Changes in the system after 1989}

The banking system in Poland underwent two transformations related to the political system after World War II. The first one took place immediately after the war due to the intervention from the outside supported by indicative planning (Jezierski, Leszczyńska, 2001). The second political system-related transformation began in 1989. The Banking Law and the Act on the National Bank of Poland (NBP) were essential for creating the new banking system. They were the basis for building the system of market banking enterprises striving mainly for profits. NBP was transformed into a modern central bank (Wójtowicz, pp. 18-25). From May 2004 NBP became member of European System of Central Banks. The ESCB comprises the European Central Bank and the national central banks (NCBs) of all EU Member States (Article 107.1 of the Treaty) whether they have adopted the euro or not. The process of setting up commercial banks and banks with foreign capital was started. Privatization of banks was made possible.

The third transformation, not related to the political system, began upon Poland's joining the European Union. The banking sector and the National Bank of Poland began activity on the Single European Market where acquis communautaire including free flow of capital and services are in force. The privatization of these rules began. NBP has launched SORBNET-EURO, a payment system enabling settling local and transnational payments in euro. The system is connected with the European TARGET (Trans-European Automated Real - time Gross - settlement Express Transfer-system).

The NBP, Bank Handlowy (since 1870), Bank Gospodarki Żywnościowej (since 1975), Pekao SA (since 1929), Bank Rozwoju Eksportu (since 1986), PKO BP (1988) 
and about 1,660 co-operative banks were making up the Polish banking system until 1989.

From February 1989 new banks began to rise in number. The record number of 45 licenses was issued in 1990. 22 banks began conducting business in that year. The process of change in the banking cooperatives was started. The licensing policy was made stricter in order to avoid setting up a large number of small, weak banks. 17 licenses were issued in 1991 and 32 banks began conducting business. The nine emerged from the NBP were commercialized at the end of 1991, i.e. they were transformed into state-owned shareholder companies. The banking sector was burdened with "bad credits" in 19921993. As a result, the licensing policy was made stricter and the minimum capital was increased to ECU 5 millions. Only 6 new licenses were issued and 12 new banks began activity. In 1993, the banking sector as a whole suffered a loss. Banks, mainly cooperatives, were going to bankruptcy. The NBP issued only one license.

The position of cooperative banks was difficult. The Act of Restructuring of Cooperative Banks and Bank Gospodarki Żywnościowej from June 24, 1994 was an attempt to improve it. BGŻ became a stock company jointly owned by the State and cooperative banks. The co-operative banking sector took on a three-level structure with BGŻ SA as a state bank, eight regional banks and associated cooperative banks. Cooperative banks were also associated in three associating banks that had been set up earlier. In 1994, foreign banks were allowed to invest in Poland on condition that a bank with financial difficulties would be acquired or financial support would be provided for it. 82 commercial banks and 1,612 cooperative banks were active at the end of that year.

The number of banks on the Polish market were so large, but there was no general system of guaranteeing deposits. Therefore, the urgent need to set up a deposit guarantee system occurred. The Act on Bank Guarantee Fund (BGF) was adopted on December 14, 1994. The Bank Guarantee Fund - an independent subject of the public law being a legal person clearly separated from the government agency - was created based on it. Two functions of the BGF have been entrusted. The first of them is connected with the common obligation to guarantee deposits. The other consists in assisting banks if their solvency is threatened. In January 1998 BGF was enabled to influence the banking regulatory policy by means, that its president participates in the works of the Banking Supervision Commission. The experience heretofore gained shows that the Fund contributes to the stability of the banking sector. Amount of warranted deposit went up considerably in 2008, which totals takes away equivalence in zloty, 50000 euro presently.

Years 1995-1997 were good for banks. However, 4 commercial banks and 93 cooperative banks went to bankruptcy. Acquisitions, mergers, privatizations and consolidations were intensified. 83 commercial banks and 1,295 cooperative banks were active at the end of 1997. The NBP fulfilled supervisory functions over banks in period of 1989-1997 (NBP, 2007: 13).

Period of 1998-2004 abounded with events on the banking market. The banking law, the NBP act and the act on debentures and mortgage - all of them from August 29, 1997 - took effect at the beginning of 1998. New supervision over banks was established. It was Banking Supervision Commission, acting to the end of 2007 (NBP, 2007: 41). The number of bankruptcies of banks decreased, few specialized banks were set up. The first mortgage bank - Rheinhyp BRE Bank Real State SA - started its operations. Mergers and 
acquisitions were strongly. 77 commercial banks and 781 cooperative banks were active in the end of 1999. The consolidation process began in the cooperative banking sector (Act on functioning of cooperative banks, their associations and associating banks).

As a result of these changes, 69 commercial banks and 642 cooperative banks were conducting operations in the end of 2001. In the end of 2002, their number was 59 and 605, respectively: 57 and 596 in the end of 2004; 52 and 579 in the end of 2008. The process of consolidation of banks got stronger in 1999-2003. The banking law was gradually aligned with European Union directives. The two-level banking system became distinct. It had a significant influence on the performance of banking system (Stefański, 2004). As a result of the privatization, the share of banks (assets of banks) controlled by the State decreased from $66,5 \%$ in 1996 to $20,5 \%$ in 2004 , and to $17,3 \%$ in 2008 . The government is only owner of the Bank Gospodarstwa Krajowego and controls (directly or indirectly) the operations of PKO BP SA, Bank Pocztowy SA and Bank Ochrony Środowiska SA. The sector is dominated by banks controlled by foreign investors which have the share about $70 \%$ from 2000 (table 1). A strong position of banks controlled by foreign investors is typical for Central European banking sectors. Their share in assets in 2003 was higher in Czech Republic: 96\%, Estonia: 97,5\%, Lithuania: 95,6\%, Hungary: 83,3\%, Slovakia: 99,6\% (more information on this subject in ECB, 2005). Similar level is still maintained (Czech Republic: 92\%; Estonia: 97\%; Lithuania: 83\%; Slovakia: 96\%; Bulgaria: 82\%; more information on this subject in ECB, 2008: 36-49).

Among many reasons of this situation, two things seem to be the most important. In the initial period of transformation, these countries lacked private investors having capital sufficient for participating in the privatization of banks. The second reason was adopting the privatization strategy for searching the industry strategic investor. The example of

Table 1. Structure of the Polish banking sector in 1996-2008

\begin{tabular}{|c|c|c|c|c|c|c|c|c|c|c|c|}
\hline \multirow{2}{*}{ Group of banks } & \multicolumn{11}{|c|}{$\begin{array}{l}\text { Number of banks conducting operations } \\
\text { (bankrupt banks and banks in liquidation are not included) }\end{array}$} \\
\hline & 1996 & 1997 & 1998 & 1999 & 2000 & 2001 & 2002 & 2003 & 2004 & 2006 & 2008 \\
\hline $\begin{array}{l}\text { 1. Commercial banks and } \\
\text { branchesof credit } \\
\text { institutions }\end{array}$ & 81 & 81 & 83 & 77 & 73 & 69 & 59 & 58 & 57 & 63 & 70 \\
\hline $\begin{array}{l}\text { 2. Banks with a majority } \\
\text { share of state capital }\end{array}$ & 24 & 15 & 13 & 7 & 7 & 7 & 7 & 6 & 5 & 4 & 4 \\
\hline $\begin{array}{l}\text { 3. Banks with a majority } \\
\text { shareof private capital } \\
\text { including: }\end{array}$ & 57 & 66 & 70 & 70 & 66 & 62 & 52 & 52 & 52 & 59 & 66 \\
\hline $\begin{array}{l}\text { 3.1. banks controlled by } \\
\text { Polish investors }\end{array}$ & 32 & 38 & 39 & 31 & 20 & 16 & 7 & 6 & 8 & 7 & 6 \\
\hline $\begin{array}{l}\text { 3.2. banks controlled by } \\
\text { foreign investors }\end{array}$ & 25 & 28 & 31 & 39 & 46 & 46 & 45 & 46 & 44 & 52 & 60 \\
\hline 4. Co-operative banks & 1394 & 1295 & 1189 & 781 & 680 & 642 & 605 & 600 & 596 & 584 & 579 \\
\hline 5. Banking sector & 1475 & 1376 & 1272 & 858 & 753 & 711 & 664 & 658 & 653 & 647 & 649 \\
\hline
\end{tabular}




\begin{tabular}{|c|c|c|c|c|c|c|c|c|c|c|c|}
\hline \multirow{2}{*}{ Group of banks } & \multicolumn{11}{|c|}{ Assets (as a percentage of the banking sector) } \\
\hline & 1996 & 1997 & 1998 & 1999 & 2000 & 2001 & 2002 & 2003 & 2004 & 2006 & 2008 \\
\hline 1. Commercial banks & 95.4 & 95.5 & 95.7 & 95.8 & 95.8 & 95.4 & 95.0 & 94.8 & 94.7 & 93.8 & 94.6 \\
\hline $\begin{array}{l}\text { 2. Banks with a majority } \\
\text { share of state capital }\end{array}$ & 66.5 & 49.3 & 45.9 & 23.9 & 22.9 & 23.5 & 25.1 & 24.4 & 20.5 & 19.8 & 17.3 \\
\hline $\begin{array}{l}\text { 3. Banks with a majority } \\
\text { share of private capital } \\
\text { including: }\end{array}$ & 28.9 & 46.2 & 49.8 & 71.8 & 72.9 & 71.9 & 69.9 & 70.4 & 74.2 & 74.0 & 77.3 \\
\hline $\begin{array}{l}\text { 3.1. banks controlled by } \\
\text { Polish investors }\end{array}$ & 15.1 & 30.9 & 33.2 & 24.6 & 3.4 & 3.2 & 2.5 & 2.6 & 6.6 & 4.3 & 5.0 \\
\hline $\begin{array}{l}\text { 3.2. banks controlled by } \\
\text { foreign investors }{ }^{1}\end{array}$ & 13.7 & 15.3 & 16.6 & 47.2 & 69.5 & 68.7 & 67.4 & 67.8 & 67.6 & 69.7 & 72.3 \\
\hline 4. Co-operative banks & 4.6 & 4.5 & 4.3 & 4.2 & 4.2 & 4.6 & 5.0 & 5.2 & 5.3 & 6.2 & 5.4 \\
\hline 5. Banking sector & 100.0 & 100.0 & 100.0 & 100.0 & 100.0 & 100.0 & 100.0 & 100.0 & 100.0 & 100.0 & 100.0 \\
\hline \multirow{2}{*}{ Group of banks } & \multicolumn{11}{|c|}{ Loans (as a percentage of loans to non-financial sector) } \\
\hline & 1996 & 1997 & 1998 & 1999 & 2000 & 2001 & 2002 & 2003 & 2004 & 2006 & 2008 \\
\hline $\begin{array}{l}\text { 1. Commercial banks and } \\
\text { branches of credit } \\
\text { institutions }\end{array}$ & 93.9 & 94.5 & 95.0 & 94.9 & 94.6 & 94.2 & 93.5 & 92.9 & 92.2 & 93.0 & 93.5 \\
\hline 2. Cooperative banks & 6.1 & 5.5 & 5.0 & 5.1 & 5.4 & 5.8 & 6.5 & 7.1 & 7.8 & 7.0 & 6.5 \\
\hline $\begin{array}{l}\text { 3. Banks with a polish } \\
\text { investors }\end{array}$ & 84.0 & 81.8 & 78.1 & 49.1 & 29.8 & 28.7 & 29.6 & 30.3 & 33.2 & 30.1 & 28.6 \\
\hline $\begin{array}{l}\text { 4. Banks with a foreign } \\
\text { investors }\end{array}$ & 16.0 & 18.2 & 21.9 & 50.9 & 70.2 & 71.3 & 70.4 & 69.7 & 66.8 & 69.9 & 71.4 \\
\hline \multirow{2}{*}{ Group of banks } & \multicolumn{11}{|c|}{ Deposits (as a percentage of deposits non-financial sector) } \\
\hline & 1996 & 1997 & 1998 & 1999 & 2000 & 2001 & 2002 & 2003 & 2004 & 2006 & 2008 \\
\hline $\begin{array}{l}\text { 1. Commercial banks and } \\
\text { branchesof credit } \\
\text { institutions }\end{array}$ & 94.5 & 94.8 & 94.8 & 95.0 & 94.8 & 94.4 & 93.8 & 93.4 & 93.0 & 91.4 & 91.2 \\
\hline 2. Cooperative banks & 5.5 & 5.2 & 5.2 & 5.0 & 5.2 & 5.6 & 6.2 & 6.6 & 7.0 & 8.6 & 8.8 \\
\hline $\begin{array}{l}\text { 3. Banks with a polish } \\
\text { investors }\end{array}$ & 87.8 & 87.3 & 86.3 & 54.4 & 36.5 & 36.1 & 37.8 & 37.4 & 37.3 & 33.5 & 32.4 \\
\hline $\begin{array}{l}\text { 4. Banks with a foreign } \\
\text { investors }\end{array}$ & 12.2 & 12.7 & 13.7 & 45.6 & 63.5 & 63.9 & 62.2 & 62.6 & 62.7 & 66.5 & 67.6 \\
\hline
\end{tabular}

Source: (BSC, 2005: 31-32) and (PFSA, 2009, Statistical Annex).

Poland proves that the funds of local governments and people's savings were not used for the privatization of banks.

The increasing share of the foreign capital in Polish banks is perceived on one hand as a opportunity of the Polish banking sector quicker growth, but on the other hand as a threat to its sovereignty (Jaworski, Zawadzka, 2001). The ownership structure is important for the stability of the banking sector because it affects the quality of the corporate governance, efficiency of work of banks and their development potential. 
A bank owned by a renowned financial institution encounters fewer obstacles in raising funds enabling its growth. Capital injections to local banks, implementation of modern management methods and on-line banking technologies are positive results of the involvement of foreign investors. They came from countries enjoying a high level of economic development: the assets of Polish banks were dominated by German, Italian, American, Dutch, Belgian, Irish, Portuguese and French capital (BSC, 2005). In the end of 2008 the assets of Polish banks are dominated by Italian, Dutch, German, American, Belgian and Irish (PFSA, 2009). As a still developing country, Poland will need foreign capital, which can help to direct the Polish banking sector for competition. During the financial crisis pointed out the necessity of government intervention in banking sector throughout buying back bank stocks even nationalization (EIU, 2009: 4-9).

The decrease of local investors share in the assets of the banking sector from $33,2 \%$ in 1998 to $6,6 \%$ in 2004 and to 5,0\% in 2008 is an alarming trend for the Polish banking sector. The big state share in the assets animates the discussion about the completion of the privatization of banks because the state is not a good owner (Chałaczkiewicz, 2003). This is confirmed by experiences of many countries. As far as this is concerned, Poland is still far behind the developed countries. However, private ownership must not be considered a "miraculous medicine" against economic issues. This thesis becomes genuine more and more in time of financial slump, in which many governments supplied private banks with capitals or even nationalized.

The privatization and consolidation of the banking sector have led to a change in its structure. There is an upward trend in the concentration of commercial banks measured with the ratio of the fifteen largest banks share in the sector assets, deposits and credits as well as fluctuations if the effect is measured with the Herfindahl-Hirschman index (table 2).

The concentration index $(\mathrm{HH})$ has been declining since 2001 although the number of banks is decreasing. The ratio of share of the fifteen largest banks is decreasing from 2001. This means that the share of small and medium banks in the banking service market is increasing. They compete with the largest banks, mainly in selected market niches.

The banking sector in the Central European countries is relatively highly concentrated. The concentration level is lower in Poland than in smaller countries of the region. The situation in the EU countries is similar: the concentration is the highest in

Table 2. Concentration of the banking sector in Poland in 1999-2008

\begin{tabular}{|l|l|l|l|l|l|l|l|l|l|}
\hline \multicolumn{2}{|c|}{ Specification (measure) } & \multicolumn{7}{c|}{ Years } \\
\cline { 3 - 10 } & & $\mathbf{1 9 9 9}$ & $\mathbf{2 0 0 0}$ & $\mathbf{2 0 0 1}$ & $\mathbf{2 0 0 2}$ & $\mathbf{2 0 0 3}$ & $\mathbf{2 0 0 4}$ & $\mathbf{2 0 0 6}$ & $\mathbf{2 0 0 8}$ \\
\hline $\begin{array}{l}\text { 1. Herfindahl-Hirschman index } \\
\text { (in points): }\end{array}$ & assets & 731 & 705 & 821 & 792 & 753 & 692 & 599 & $640^{*}$ \\
\hline \multirow{2}{*}{$\begin{array}{l}\text { 2. Ratio of share of the fifteen largest } \\
\text { banks (in percentage): }\end{array}$} & assets & 79.0 & 78.8 & 82.4 & 82.6 & 81.1 & 79.9 & 76.6 & 73.2 \\
\cline { 2 - 10 } & deposits & 83.5 & 82.6 & 85.4 & 85.6 & 84.8 & 82.9 & 80.8 & 78.4 \\
\cline { 2 - 10 } & credits & 77.5 & 76.8 & 81.3 & 79.9 & 78.2 & 77.2 & 75.2 & 73.7 \\
\hline
\end{tabular}

* date 2007

Source: (BSC, 2005: 41; ECB, 2009: 38) and (PFSA, 2009, Statistical Annex). 
Belgium, Estonia, Finland, Netherlands, Lithuania and lower in large countries such as Germany, United Kingdom, Spain and Italy. The absolute size of the banking service market is much larger in those countries which creates opportunities for profitable operations for a larger number of entities (ECB, 2009: 36).

\section{Economic and financial standing of banks}

Essential ratios describing the financial stability of banks include liquidity, financial result, solvency, return on assets and return on equity.

Liquidity of banks means their ability to pay current liabilities. Temporary difficulties in satisfying creditors may impose selling assets below their value which generates losses for the bank. Maintaining liquidity entails alignment of receivables and payables according to maturity dates and due dates. The gap analysis is designed for this purpose among other things (Białek, 1994). The gap consists in the difference between assets and liabilities with a given maturity period. The major source of the risk of liquidity loss is the mismatch between contractual maturities of assets and liabilities and turbulence on global financial markets. Consequently to the escalation of the financial crisis and further decrease in confidence between market participants there was a limitation of market liquidity and practical elimination of transactions with longer maturities. This was also visible in Poland (PFSA, 2009: 65).

Despite the relatively stable situation in respect of liquidity, the following negative aspects should be mentioned. The first is increased mismatch between assets and liabilities with to maturities of up to 1 month and over 1 year. The negative gap for up to 1 month increased from PLN 257,0 billions in the end of 2007 to PLN 274,1 billions in the end of 2008, and the positive gap for over 1 year - from PLN 277,8 billions to PLN 368,8 billions respectively. The increase in the mismatch was a consequence of the very fast growth of lending, which was developed on the basis of short-term liabilities and the liquidation of part of liquid assets, mainly amounts due from the financial sector. The second is fast growing negative balance in settlements with the financial sector, resulting from expansive lending policy. Consequently, liquidity decreases and sensitivity to situation on financial markets increases. Positive aspects include the increase in stable deposits from PLN 235, 1 billions (2007) to PLN 302,4 (2008) (PFSA, 2009: 66). Despite the increase in value, the share in the balance sheet total slightly lowered to $29 \%$.

The stability of sources of financing is also very important. Stable sources include deposits of households and enterprises; deposits of financial institutions (including banks) are deemed to be less stable. Financing a large part of the operations of the bank with deposits of financial institutions is dangerous due to their large amounts and short due dates. Withdrawal of such deposit may cause payment problems for the bank and impose selling assets on it. Deposits of non-financial entities, especially households and SMEs not cause such danger due to, among other things, their small amounts. The so-called residue effect occurs in the liabilities of the bank for periods longer than contractual (Dobosiewicz, Marton-Gadoś, 2005). 
In 1996-2004, the share of payables to the financial sector in the balance sheet of the banking sector amounted to $11-20 \%$ and to the non-financial sector $58-65 \%$ accordingly. In 2008 it was $23,3 \%$ and $47 \%$ respectively. Decrease results in intermediaries role of banks in transformation savings on investments is called in economic literature disintermediation (Hawken, 1981). It results from different authors, that households piled in Poland in banks, in the form of deposits in $2007-43,7 \%$ of global savings and respectively: in $2008-55,4 \%$; in 1998 - 85,8\% (Stefański, 2006a: 256; NBP, 2009: 49). The share of payables to the non-financial sector from the four largest banks in Poland is shown in table 3. They enabled stating a high stability of the sources of financing of the largest Polish banks although the share of payables to non-financial institutions decreased in some of them.

Table 3. Share of payables to the non-financial sector in the liabilities of the four largest banks in Poland (in $\%)$

\begin{tabular}{|l|c|c|c|c|c|}
\hline \multirow{2}{*}{\multicolumn{1}{|c|}{ Banks }} & \multicolumn{5}{c|}{ Years } \\
\cline { 2 - 6 } & $\mathbf{1 9 9 9}$ & $\mathbf{2 0 0 2}$ & $\mathbf{2 0 0 3}$ & $\mathbf{2 0 0 4}$ & $\mathbf{2 0 0 8}$ \\
\hline 1. PKO BP SA & 90.1 & 85.6 & 84.5 & 82.9 & 75.7 \\
\hline 2. Pekao SA & 74.6 & 73.8 & 72.1 & 69.9 & 27.9 \\
\hline 3. BRE SA & 42.7 & 37.6 & 37.7 & 52.1 & 45.7 \\
\hline 4. ING Bank Śląski SA & 69.4 & 73.7 & 73.4 & 74.6 & 60.3 \\
\hline
\end{tabular}

Source: Own calculations based on information obtained from the banks.

The share of liquid assets, i.e. balance sheet items that can be relatively quickly used for satisfying creditor's claims, remained high in 1996-2003 as well. The liquid assets to total assets ratio was 33-43\% (liquid assets include cash, funds on the NBP account, bank deposits with maturity of up to 1 month, debt securities admitted to public trade, mutual fund units). The amount of the liquid assets exceeded payables to institutional depositors. The liquid assets ratio lowered to $29 \%$ in the end of 2008 and it was negative trend.

The liquidity of banks can also be determined using credits to deposits ratio (non-financial sector deposits and credits were used). That ratio was growing up to $77 \%$ from the beginning of 1990's to 2000 because the dynamics of credits exceeded that of savings significantly. It decreased to $68 \%$ in $2000-2001$. In 2002, as interest rates were decreased and the tax on capital revenues from interest rates on deposits was introduced, the increase rate of deposits declined; a nominal decrease was noted at the end of that year. A quick increase in credits extended by banks at the same time caused growth of the credit to deposit ratio to about $76 \%$ in 2003-2004. In 1996-2004, the ratio was contained in the $64-77 \%$ range. These values are believed to be safe. The liquidity of a bank would deteriorate if the value of the ratio was close to $100 \%$ or if the amount of the credits extended the amount of the deposits accepted. Such situation appeared in Poland in 2007 and credit to deposit ratio increased to $125,3 \%$ in the end of 2008 . This index is adverse, but it wrote down it in many countries (Fitch Ratings, 2008). Such situation was kept in the first quarter of 2009. 
The satisfactory liquidity of Polish banks is confirmed by ratings assigned by agencies (table 4). The ten largest banks (62,5\% of banking sector assets in 2008) are assessed positively as far as short-term payables are concerned. Ability of six banks to pay them was assessed very good and that of three other was assessed good.

Table 4. Moody's short-term ratings of 10 largest commercial banks (June 2009)

\begin{tabular}{|l|c|}
\hline \multicolumn{1}{|c|}{ Bank } & STMR \\
\hline PKO BP SA & P-1 \\
\hline Pekao SA & P-1 \\
\hline BRE SA & P-2 \\
\hline ING Bank Śląski SA & P-1 \\
\hline BZ WBK SA & P-1 \\
\hline Millennium SA & P-2 \\
\hline Bank Handlowy SA w Warszawie & P-2 \\
\hline Kredyt Bank SA & P-1 \\
\hline Getin Bank SA & NP \\
\hline BGŻ SA & P-1 \\
\hline
\end{tabular}

1 STMR - Short Term Most Recent Rating; NP - Issuers (or supporting institutions) rated Not Prime do not fall within any of the Prime rating categories; $\mathrm{P}-1$ (Prime-1) means a very strong capacity for timely payment); P-2 (Prime-2) - strong capacity.

Source: www.moodyseurope.com/ratinglist/.

Banks' is generating a positive result for their stability. Banks' profits are the main source of increases in capital which, in turn, enhance their ability to further expand and absorb losses, if any. In 1997-2004, banks' profits after tax were sinusoidal trend and increased in 2008 very strongly (chart 1). In 2008, net profit of the banking sector amounted to PLN 13,9 billions, which was the historical peak, but it was higher by $2,1 \%$ only than in 2007. Out of 649 banks and branches of credit institutions conducting operations, the majority reported better financial results than in 2007.85 banks reported deterioration of financial results (22 commercial banks, 5 credit institutions and 58 cooperative banks). Nearly $40 \%$ of the profit of the banking sector was generated by two largest banks: PKO BP SA and Pekao SA, which emphasizes their dominant role in the sector.

The comparison of the net profit (after tax) of the banking sector in 1997-2008 shows its dependence on the economic situation and policy. After two poor years, 2004 and further were a record years for banks as far as profits are concerned. Banks owe those good results to a better economic situation and the increase in demand for banking services. Due to the improvement in customers' standing, provisions did not have to be as large as in two preceding years. Better results were also due to the completion of the restructuring by most of the banks and the decrease in the corporate income tax rate from $27 \%$ to $19 \%$. However, performance ratios - NIM, ROA, ROE and CIR - as well as profitability and cost level ratios show a downward trend (table 5). Such situation is 
Chart 1. Profit after tax generated by banks in Poland in 1997-2008

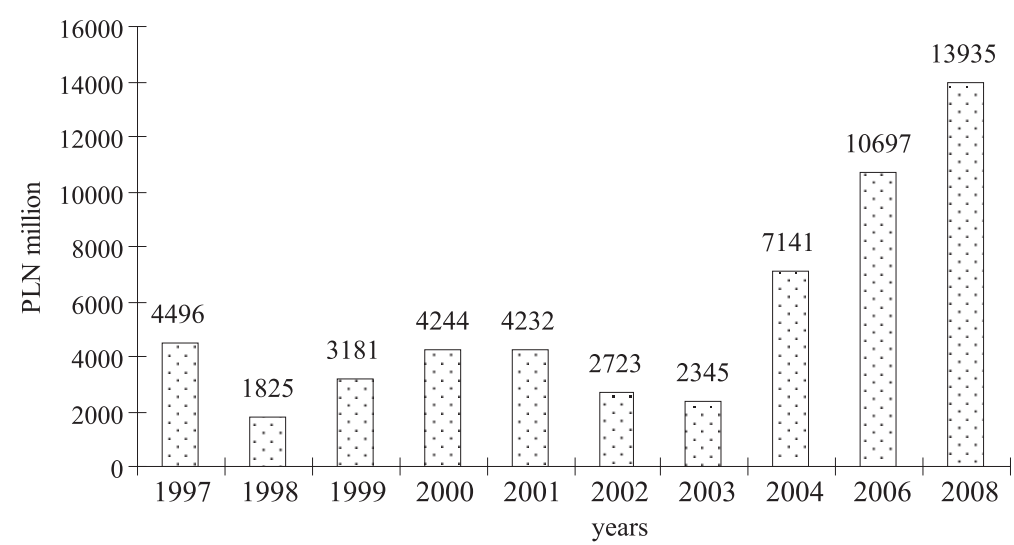

Source: (Stefański, 2004; BSC, 2005) and (PFSA, 2009: 58).

Table 5. Selected performance and profitability ratios of banks in 1997-2008 (in \%)

\begin{tabular}{|l|r|r|r|r|r|r|r|r|r|r|}
\hline \multirow{2}{*}{ Ratios } & \multicolumn{10}{|c|}{ Years } \\
\cline { 2 - 13 } & $\mathbf{1 9 9 7}$ & $\mathbf{1 9 9 8}$ & $\mathbf{1 9 9 9}$ & $\mathbf{2 0 0 0}$ & $\mathbf{2 0 0 1}$ & $\mathbf{2 0 0 2}$ & $\mathbf{2 0 0 3}$ & $\mathbf{2 0 0 4}$ & $\mathbf{2 0 0 6}$ & $\mathbf{2 0 0 8}$ \\
\hline NIM & 5.6 & 4.8 & 4.2 & 4.2 & 3.7 & 3.4 & 3.2 & 3.3 & 3.3 & 3.4 \\
\hline ROA & 2.1 & 0.7 & 1.0 & 1.0 & 1.0 & 0.5 & 0.5 & 1.5 & 1.8 & 1.6 \\
\hline ROE & 34.1 & 9.1 & 12.9 & 14.2 & 13.1 & 5.8 & 5.8 & 17.6 & 22.4 & 21.2 \\
\hline CIR & 55.0 & 62.2 & 63.2 & 62.3 & 61.6 & 63.9 & 68.2 & 65.1 & 58.6 & 54.7 \\
\hline Gross profitability & 19.5 & 9.9 & 10.7 & 8.9 & 7.0 & 4.5 & 6.2 & 11.0 & 15.5 & 10.6 \\
\hline Net profitability & 13.2 & 3.9 & 6.7 & 6.3 & 5.1 & 2.7 & 3.2 & 10.0 & 12.7 & 8.7 \\
\hline CL & 83.7 & 91.0 & 90.4 & 92.3 & 93.5 & 95.7 & 94.2 & 90.1 & 86.6 & 89.4 \\
\hline
\end{tabular}

NIM - Net Interest Margin (interest income / average assets minus mature interest on irregular receivables);

ROA - Return on Assets (profit after tax / assets minus mature interest on irregular receivables);

ROE - Return on Equity (profit after tax / equity); it should exceed 15\%;

CIR - Cost-Income-Ratio - operating costs (operations and depreciation) to banking operations result ratio;

Gross profitability - result before tax to total costs ratio;

Net profitability - result after tax to total costs ratio;

$\mathrm{CL}$ - cost level (total costs to total revenues).

Source: (BSC, 2005), (BSC, 2007) and (PFSA, 2009, Statistical Annex).

advantageous in case of indicators only CIR and CL. Ratios of cooperative banks are much better than those of commercial banks except CIR.

Banks are obliged to maintain equity at a level ensuring security of the deposits and enabling coverage of unexpected losses. Prudence regulations of the Polish Financial Supervision Authority set forth detailed minimum capital requirements imposed on banks. Banks' equity funds (so-called regulation capital) in relation to the total of so-called capital requirements by virtue of each risk should not be lower than $15 \%$ and $12 \%$ in the first and the second year of the operations of the bank and not lower than $8 \%$ in each subsequent year. Banks' equity funds should be no lower than $8 \%$ of capital requirements according to Capital Requirement Directive, called Basel II (Stefański, 2006). 
Table 6. Local banks by solvency ratio in 2006-2008 (as a percentage of the total number)

\begin{tabular}{|l|c|c|c|c|}
\hline \multicolumn{2}{|c|}{ Ratio in \% } & $\mathbf{2 0 0 6}$ & $\mathbf{2 0 0 7}$ & $\mathbf{2 0 0 8}$ \\
\hline below 8 & a & 0.0 & 0.0 & 1.9 \\
\hline & b & 0.2 & 0.2 & 0.2 \\
\hline over 8- below 10 & a & 3.9 & 8.0 & 23.0 \\
\hline & b & 10.3 & 10.8 & 6.0 \\
\hline over 10- below 12 & a & 19.6 & 38.0 & 32.8 \\
\hline & b & 14.7 & 16.0 & 23.0 \\
\hline over 12- below 15 & a & 35.3 & 20.0 & 11.5 \\
\hline & b & 21.6 & 20.5 & 25.6 \\
\hline over 15 & a & 41.2 & 34.0 & 30.8 \\
\hline & b & 53.2 & 52.5 & 45.2 \\
\hline
\end{tabular}

a - commercial banks

b- cooperative banks

Source: Own calculations on the basis ( PFSA, 2009).

The analysis of solvency of banks in 1992-2006 shows a great improvement. The percentage of commercial and cooperative banks with solvency ratios in the $8-30 \%$ range was growing constantly. Financial crisis and the new capital requirements resulted in the deterioration of the solvency ratio of banks (table 6). At the beginning of 2008 full implementation of all provisions of CRD into the Polish system was carried out. In 2008 own funds of the banking sector increased from PLN 61,8 billions in 2007 to PLN 75,0 billions. The increase in own funds was mainly due to the increase in core funds (due to the fact that $60 \%$ of profits for 2007 was left at banks). All commercial banks met the requirement of holding minimum own funds at the level of EUR 5 millions. Due to the rapid depreciation of PLN, in the second half of 2008, 79 cooperative banks did not meet the requirement of holding minimum own funds at the level of EUR 1 million in the year-end. In 2008 total capital requirement increased from PLN 40,7 billions in the end of 2007 to PLN 55,6 billions in the end of 2008.

The increase in total requirement was caused by two factors. Firstly, due to very high growth of lending activity credit risk rose and in the end of 2008 the requirement in this respect accounted for $87,6 \%$ of the total requirement. Secondly, it was necessary to take into account the operational risk requirement in capital adequacy account from the beginning of 2008 and in the end of the year capital requirement in this respect accounted for $10,2 \%$. The importance of other requirements was marginal $(2,2 \%)$. The increase in the total capital requirement was not offset by sufficiently large increase in own funds. As a consequence, the average capital adequacy ratio of the banking sector decreased from $12,1 \%$ (2007) to $10,8 \%$ (2008). The lower capital adequacy ratio was observed mainly in commercial banks, where it dropped from $12,0 \%$ to $10,7 \%$. In cooperative banks, the average capital adequacy decreased only from $13,8 \%$ to $13,2 \%$ (PFSA, 2009: 72-74). Assuming, capital adequacy of the banking was satisfactory. The funds held by banks sufficiently covered the risk related to their operations and permitted their further development. 
WsPótczesna EKonomia

Table 7. Moody's long-term ratings of the ten largest banks (June 2009)

\begin{tabular}{|l|c|}
\hline \multicolumn{1}{|c|}{ Bank } & LTR $^{\mathbf{1}}$ \\
\hline PKO BP SA & A2 \\
\hline Pekao SA & A2 \\
\hline BRE SA & A3 \\
\hline ING Bank Śląski SA & A2 \\
\hline BZ WBK SA & Baa2 \\
\hline Millennium SA & A3 \\
\hline Bank Handlowy SA w Warszawie & A3 \\
\hline Kredyt Bank SA & A2 \\
\hline Getin Bank SA & Ba3 \\
\hline BGŻ SA & A3 \\
\hline
\end{tabular}

${ }^{1}$ LTR - Long Term Rating; A - good credit quality; Baa - adequate credit quality; Additional numbers mean the place of the bank within basic letter-marked classes: 1 means that the bank is located in the better part of the class, 2 means the middle part and 3 - the lower part.

Source: as for table 4 .

Table 8. Moody's financial strength ratings of the ten largest banks (June 2009)

\begin{tabular}{|l|c|}
\hline \multicolumn{1}{|c|}{ Bank } & BFSR \\
\hline PKO BP SA & C- \\
\hline Pekao SA & C- \\
\hline BRE Bank SA & D \\
\hline ING Bank Śląski SA & D+ \\
\hline BZ WBK SA & D+ \\
\hline Millennium SA & D \\
\hline Bank Handlowy SA w Warszawie & D+ \\
\hline Kredyt Bank SA & D \\
\hline Getting Bank SA & D- \\
\hline BGŻ SA & D \\
\hline
\end{tabular}

${ }^{1}$ BFSR - Bank Financial Strength Rating.

Source: as for table 4.

Long-term payment capacity of ten banks was rated good (table 7). This confirms that the Polish banking sector is relatively stable.

Rating agencies also analyses banks' operations as a whole (so-called financial strength of banks, BFSR). They are marked from A to E, according to agency. The first mark (A) means a high reliability and financial strength of the bank, the latter mark (E) is a very low financial strength close to the loss of payment capacity. Signs "+" and "_." meaning that the class assigned is temporary and the bank may be upgraded or downgraded are often added. The analysis of the financial strength of Polish banks allows to believe that they are rather weak (table 8).

\section{8}


Economic crisis has made the prospects of the financial position of banks deteriorated. The banking industry as a whole will be able to absorb the effects of the crisis without jeopardizing the safety of its operation. Analyses confirm this thesis (NBP, 2009a: 31-83). The special European Union overview shows which type of measures have so far been taken by individual member states that decided to intervene in support of financial institutions. In the period of 2007-2009 Polish government did not provide assistance to banks (CEC, 2009a: 15-16). This fact confirms its good financial situation.

\section{Banking sector development trends}

The banking market in Poland is dominated by 15 banks, the assets of which are about $80 \%$ of total sector assets. Therefore, other banks hold about $15 \%$ of assets taking into account the share of the cooperative banks. Those are small banks, often regional or highly specialized.

No major consolidation of banks took place in period of 2002-2004 (Stefański, 2004). However, it should be expected soon because the economic potential of banks in Poland is low. PKO BP SA, the largest Polish bank, has 180 place in the world-wide ranking of banks by own funds in 2008 and fourth in the Central Eastern European Countries (The Banker, 2009). Such consolidation will also reflect mergers world-wide. If two institutions merge, they consolidate their businesses or sell them to other institutions. It can be expected that any bank in the world may be acquired except for the first twenty by balance sheet total and market capitalization. Moreover, the banking sector is believed to be the most scattered and, therefore, numerous mergers and acquisitions are forecast for the years to come. It is even expected that $30 \%$ of the global banking market will be controlled by three large financial institutions (ATKEARNEY, 2004). The implementation of the rules of the New Capital Agreement (Basel II) will cause a great wave of acquisitions and mergers (Charofas, 2004). Banking sector structure did not change significantly in period of 2004-2008. The number of domestic commercial banks decreased from 54 to 52. The number of branches of credit institutions increased from 3 to 18 in the same period. The number of cooperative banks decreased from 596 to 579 .

The most important changes that would have the greatest impact on the banking sector structure may include the planned mergers of banks:

1)GE Money Bank SA with Bank BPH SA;

2)Getin Bank SA with Noble Bank SA;

3)Sygma Bank SA with Cetelem Bank SA;

4)Santander Consumer SA with AIG Bank Polska SA.

Moreover, establishment of new branches of credit institutions is also planned, but the global crisis may make changes of plans of certain investors. Another consequence of the crisis may also be changes of strategic investors of Polish banks, in cause of rapid weakening of financial condition of the parent company. They may decide to sell business in Poland. Outside the territory of Poland, 4 banks conducted operations in the form of banking companies or branches (PFSA, 2009: 33).

Research results show that banks should return to concentrating on deposit and credit activity. They also require great regulation and oversight (EIU, 2009: 6-7). 


\section{Polish banking sector in the context of European Union banking sector}

Polish banking sector is an integral element of the European banking system. Therefore it is worth to compare it with other European Union Member States (Stefański, 2006b: 76-96). Considering the strong impact of financial crisis from years 2007-2008 on banks' results do not to present date on performance of banking operations, but only to present structural date (ECB, 2008: 76-106 and Annex). Dates are contained in table 9. Author is presented only chosen financial indicators of banking sectors of EU members in period of 2004-2006.

In terms of assets, Polish banking sector is still small in comparison with EU-15. Its assets hardly account for $1 \%$ of total assets of all EU member states, but on the other hand it is the largest among the new member states accounting for over $30 \%$ of total assets in this group. It is characteristic of Poland, as it is in the case of other new EU member states, that not only the banking sector assets are very low, but also the relationship between those assets and GDP. On the one hand, this proves that the economy has low "banking culture", but the other hand, this sector has great growth potential. In 2008 assets to GDP ratio rapidly increased in Poland. Due to high increase in mortgage loans for households in the last years, their share in GDP grew considerably, although it is still much lower than in most EU members. However, the relatively low share in GDP does not equal low risk for the sector.

Considering the number of operating credit institutions, Polish banking sector is one of largest in Europe. However, the number of branches per 1 million residents is below average. The level of concentration of the Polish banking sector, measured by the share of the five largest banks in total assets of banking sector is slightly over the EU average level. Ownership structure of the Polish banking sector is characteristic for the new EU member states, where the share of foreign investors is very high.

The scope of operations of the Polish banking sector in the context of highly developed EU member states is low, which proves low level of " banking culture" of Polish economy and the development potential of the sector.

A bank's interest margin is one of the most important indicators of the cost of financial intermediation. The NIM can be used as an indicator for the actual degree of competitive condition of the market, but can also reflect other factors, such as market power and risk appetite. NIM in Bulgaria, the Czech Republic, Estonia, Greece, Hungary, Latvia, Lithuania, Poland, Romania, Slovakia and Slovenia were substantially higher than the EU average (CEC, 2009: 19). It was with values ranging from 2,12\% to 3,82\% in 2006 against on EU average of $1,87 \%$.

Looking at the net non interest margins (NNM), it is higher in the new EU-12 members than in the old EU-15 members, i.e., over the period 2004-2006 the average NNM was up to $72 \%$ higher in the EU-12 compared to the average NNM in the EU-15.

The efficiency of national banking markets, measured by the cost-to-income ratio, which is a ratio expressing a company's cost effectiveness differences between EU-15 and EU-12 were marginal on average in period of 2004-2006 (CEC, 2009: 22-23).

Despite marginal differences in cost-to-income ratios there were substantial differences between the levels of expenses as a percentage of total assets across various 
Table 9. Polish banking sector in the context of other European Union Member States at the end of 2007

\begin{tabular}{|c|c|c|c|c|c|c|c|c|c|c|c|}
\hline Country & 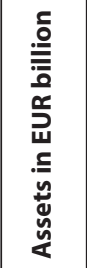 & 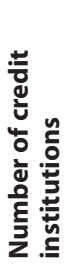 & 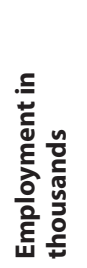 & 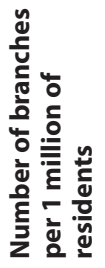 & 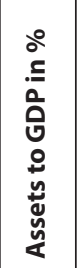 & 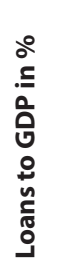 & 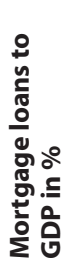 & 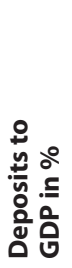 & 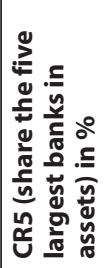 & 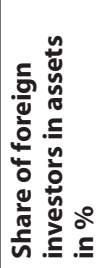 & 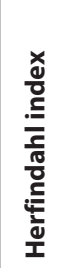 \\
\hline Austria & 891 & 803 & 78 & 514 & 329 & 139 & 24 & 111 & 43 & 27 & 527 \\
\hline Belgium & 1298 & 110 & 67 & 417 & 392 & 126 & 34 & 155 & 83 & 25 & 2079 \\
\hline Bulgaria & 31 & 29 & 31 & 767 & 107 & 66 & 10 & 68 & 57 & 82 & 833 \\
\hline Cyprus & 91 & 215 & 11 & 1151 & 607 & 273 & 47 & 350 & 65 & 32 & 1082 \\
\hline Czech Republic & 140 & 56 & 40 & 181 & 110 & 53 & 15 & 73 & 66 & 92 & 1100 \\
\hline Denmark & 978 & 189 & 50 & 399 & 429 & 221 & 104 & 79 & 64 & 19 & 1120 \\
\hline Estonia & 21 & 15 & 6 & 205 & 131 & 96 & 35 & 57 & 96 & 97 & 3410 \\
\hline Finland & 288 & 360 & 25 & 309 & 160 & 82 & 35 & 56 & 81 & 65 & 2540 \\
\hline France & 6682 & 808 & 479 & 622 & 353 & 114 & 34 & 83 & 52 & 13 & 679 \\
\hline Greece & 383 & 63 & 65 & 344 & 167 & 87 & 28 & 109 & 68 & 23 & 1096 \\
\hline Spain & 2945 & 357 & 276 & 1013 & 281 & 177 & 59 & 144 & 41 & 12 & 459 \\
\hline The Netherlands & 2195 & 341 & 114 & 220 & 392 & 193 & 70 & 157 & 86 & 18 & 1928 \\
\hline Ireland & 1337 & 81 & 42 & 269 & 715 & 257 & 66 & 175 & 46 & 47 & 600 \\
\hline Lithuania & 24 & 80 & 10 & 285 & 86 & 63 & 17 & 42 & 81 & 83 & 1827 \\
\hline Luxembourg & 915 & 156 & 26 & 470 & 2542 & 533 & 41 & 822 & 28 & 95 & 276 \\
\hline Latvia & 31 & 31 & 13 & 297 & 155 & 104 & 34 & 72 & 67 & 58 & 1158 \\
\hline Malta & 38 & 22 & 4 & 260 & 760 & 405 & 40 & 280 & 70 & 42 & 1174 \\
\hline Germany & 7562 & 2026 & 691 & 483 & 312 & 130 & 40 & 119 & 22 & 11 & 183 \\
\hline Poland & 221 & 712 & 174 & 354 & 67 & 36 & 10 & 36 & 47 & 71 & 640 \\
\hline Portugal & 440 & 175 & 61 & 569 & 270 & 158 & 62 & 118 & 68 & 23 & 1097 \\
\hline Romania & 72 & 42 & 66 & 295 & 60 & 35 & 3 & 32 & 56 & 82 & 1041 \\
\hline Slovakia & 50 & 26 & 20 & 216 & 91 & 45 & 11 & 57 & 68 & 96 & 1082 \\
\hline Slovenia & 43 & 27 & 12 & 356 & 126 & 86 & 8 & 58 & 60 & 29 & 1282 \\
\hline Sweden & 846 & 201 & 44 & 203 & 255 & 134 & 40 & 57 & 61 & 9 & 934 \\
\hline United Kingdom & 10093 & 390 & $453^{*}$ & 204 & 500 & 288 & 54 & 290 & 41 & 53 & 449 \\
\hline Hungary & 109 & 206 & 42 & 335 & 108 & 65 & 12 & 51 & 54 & 57 & 839 \\
\hline Italy & 3332 & 821 & 342 & 560 & 217 & 112 & 17 & 73 & 33 & 17 & 330 \\
\hline EU27 & 41072 & 8348 & 3240 & 471 & 334 & 157 & 41 & 136 & 44 & 29 & 1102 \\
\hline
\end{tabular}

* 2006 data

Source: (PFSA, 2009: 80; ECB, 2008: 38). 
member states. A clear distinction could be seen between EU-15 and EU-12 banking markets, with the latter having a substantially higher expense ratios. It is therefore interesting to examine how this figure relates to overall profitability (CEC, 2009: 22).

Return on Equity (ROE) reflects the efficiency of own capital. There were substantial differences between individual member states as well as between the EU-15 and the EU-12 in the period of 2004-2006. The average ROE was 17,5\% in the EU-15 and 20,9\% in the EU-12. Austria, Belgium, Bulgaria, the Czech Republic, Estonia, France, Hungary, Latvia, Lithuania, Poland, Slovakia, Spain and Sweden had profitability levels over the EU-27 average level. The favourable economic conditions up to the summer of 2007 have been an important driver for increasing overall profitability figures (CEC, 2009: 23). Overall, ROE have declined due to financial turmoil, after 2007.

Polish banking sector has achieved positive indicators of effectiveness in 2008 (ECB, 2009a: 45-47). Ratio of solvency was also for good horizontal (ECB, 2009a: 54-57). Polish banking sector is profitably presented on the background of banking sectors of countries members of the European Union. Big number of banks (13) among fifty the biggest banks in the Central and Eastern Europe region shows also power of polish banking sector (Rzeczpospolita, 2009: 27).

\section{Conclusions}

It is possible to ascertain on the base carried through analysis, that banking sector underwent in Poland several processes in years 1989-2008. They were:

- demonopolization,

- liberalization (deregulation),

- restructuring,

- privatization,

- globalization (internationalization),

- consolidation.

The Polish banking sector is stable and banks have to adopt a strategy that will enable them to compete on the Single Market. The strategy should be based on a change of the structure of revenues and costs, and on modification of the credit extending procedure. This is confirmed by the comparison of the banking sector in Poland with the banking sector of the best developed European Union countries. Differences are too big.

The assets of the banking sector to GDP ratio in Poland was $82 \%$ in 2008 . It was higher than in almost all the new member countries (expecting Romania) and amounted to about $334 \%$ on the average level in European Union countries.

The number of inhabitants per branch in Poland was 3284 in 2007 (Austria - 1949, Spain - 986, France - 1607, Germany -2068). It was higher than the average level in EU countries (EU-27 - 2123).

The value of assets per employee was EUR 1357 thousands in 2007. Lower value was written down in Bulgaria and Romania. It means that efficiency of the Polish banking sector was low.

Population per ATM in Poland was 3837 in 2006 and it was the largest number in EU (Romania - 3575; average level in EU-27 - 1362). The percentage margin or the 
difference between the average interest rate on credits and deposits is twice high in Poland as in EU-15 countries. Its further decline is expected. It may be very painful for banks in Poland bearing in mind the long-term trend to decrease interest rates.

Finally, the free flow of capital will also make Polish banks decrease bank charges, much higher than in other EU-15 countries.

\section{References}

ATKEARNEY, Banks Shift Gears in Drive for Top-Line Growth, 2004.

Banking Supervision Commission, Financial standing of banks in 2004, Warsaw 2005.

Banking Supervision Commission, Financial standing of banks in 2006, Warsaw 2007.

Białek G.., Principles of cash management in commercial bank, TWIGGER, Warsaw 1994.

CEC (Commission of the European Communities), European financial integration report, Brussels, 09 January, 2009.

CEC (Commission of the European Communities), Special edition on state aid interventions in the current financial and economic crisis. Report from the Commission, Brussels, 08 April, 2009a.

Chałaczkiewicz M., End banks privatisation should be priority of economic policy, „Rzeczpospolita”, No 303, 2003.

Charofas D.N., Economic capital allocation with Basel II (cost, benefit and implementation procedures), Elsevier Butterworth-Heinemann, Oxford 2004.

Hawken P., Disintermediation: an economics buzzword that neatly explains a lot of the good that is going on, Co Evolution Quarterly No 29, 1981.

Dobosiewicz Z., Marton-Gadoś K., Principles of banking with exercises, PWN, Warsaw 2005.

$\mathrm{ECB}(2004)$, Report on EU banking structure.

$\mathrm{ECB}(2004)$, The monetary policy of the $E C B$.

$\mathrm{ECB}(2005)$, Banking structures in the new EU members states.

ECB(2008), UE banking structures.

ECB(2009), Financial stability review.

ECB(2009a), European Union banking sector stability.

EIU (Economist Intelligence Unit), Risk and regulation: a new era for capitalism, London 2009.

Fitch Ratings, Bank systemic risk report, October 21, 2008.

Jaworski W.L., Zawadzka Z., Banking, Poltext, Warsaw 2001.

Jezierski A., Leszczyńska C., National Bank of Poland, NBP, Warsaw 2001.

NBP, Nadzór bankowy 1989-2006, Warsaw 2007.

NBP, Sprawozdanie z wykonania założeń polityki pieniężnej w 2008 r., Warsaw, May 2009.

NBP, Financial stability report, Warsaw, June 2009.

PFSA, Report on the condition of Polish banks in 2008, Warsaw 2009.

"Rzeczpospolita", Top 50 biggest banks, dodatek specjalny z 10 września 2009.

Stefański M., The Polish banking system in the transition period-selected aspects, „Bank i Kredyt”, No 2, Warsaw 2004.

Stefański M., New regulations concerning capital requirements to banks, "Working Papers" No 212 , NBP, Warsaw 2006.

Stefański M., Directions in the evolution of the banking sector in Poland after 1989, WSHE, Włocławek $2006 \mathrm{a}$.

Stefanski M., Banking sectors in new EU member states; their economic position and financial strength, Social Sciences Bulletin 2006, No 2, Daugavpils University, 2006b.

The Banker, Top 1000 World Banks 2009, London, July 2009.

Wójtowicz G.., Bank centralny w gospodarce rynkowej, w: Bankowość centralna od A do Z, NBP, Warsaw.

Zaleska M., Charakterystyka systemu bankowego-uwarunkowania instytucjonalne, [in:] Zaleska M. (ed.), Wspótczesna bankowość, t. I, Difin, Warszawa 2007. 


\section{Transformacja polskiego sektora bankowego}

\section{Streszczenie}

Głównym celem opracowania jest prezentacja wybranych aspektów polskiego sektora bankowego w latach 1989-2008. Autor podjat próbę odpowiedzi na następujace pytania: (1) Czy polski sektor bankowy jest stabilny? (2) Czy banki prowadzace działalność operacyjna w Polsce sq przygotowane do konkurowania na Jednolitym Rynku Europejskim? (3) Jaka jest pozycja polskiego sektora bankowego w sektorze bankowym państw Unii Europejskiej?

Po drugiej wojnie światowej system bankowy przeszedt, w tym także i sektor, przeszedt dwie ważne transformacje ustrojowe: po 1946 r. i po 1989 r. Trzecia transformacja zaczęta się 1 maja 2004 r., ale ona nie ma charakteru ustrojowego. Polski sektor bankowy rozpoczał funkcjonowanie na Jednolitym Rynku Europejskim i przygotowuje się do przyjęcia wspólnej waluty euro.

W pierwszej części opracowania przedstawiono przemiany w sektorze bankowym po 1989 r., wskazujac na procesy demonopolizacji, liberalizacji, restrukturyzacji, prywatyzacji, globalizacji (umiędzynarodowienia) i konsolidacji. Przedstawione procesy zachodziły $w$ bankach komercyjnych i spółdzielczych z różnym nasileniem i nie były równoległe. W drugiej części opracowania podjęto próbę analizy sytuacji ekonomiczno-finansowej banków $w$ Polsce. Polskie banki byly stabilne $w$ analizowanym czasie i posiadaly ptynność finansowa, co potwierdzono $w$ raportach NBP i instytucji ratingowych. Taka ocene potwierdza także fakt braku interwencji finansowej $w$ sektor bankowy ze strony polskiego rzqdu. Porównanie zysków banków w latach 1997-2008 wskazuje na ich zależność od sytuacji ekonomicznej i politycznej Polski. Banki w Polsce posiadały wskaźniki adekwatności kapitałowej wyższe, niż wymagane minimum. Ocena sity finansowej polskiego sektora bankowego nie była korzystna. Z badań autora wynika, że jego udziat $w$ sektorze bankowym państw UE nie jest adekwatny do udziatu polskiego PKB w PKB wszystkich państw UE (znacznie niższy). Wskazano też na zachodzacy proces dezintermediacji, który nasilat się wraz z rozwojem rynku kapitałowego. W trzeciej części opracowania skoncentrowano się na kierunkach rozwoju polskiego sektora bankowego w najbliższych latach, wskazujac na konieczność dokończenia prywatyzacji banków i dalsza ich konsolidację. Dalszy rozwój polskiego sektora bankowego uzależniony będzie od decyzji inwestorów zagranicznych, którzy posiadaja w nim silna pozycję. Kryzys finansowy mo$\dot{z}$ e spowodować, że będa ono ograniczać zaangażowanie kapitałowe w polskim sektorze bankowym na rzecz umacniania macierzystych instytucji kredytowych. W czwartej części przedstawiono polski sektor bankowy na tle sektora bankowego państw UE. Z analizy wynika, że jego potencjat finansowy jest niski i charakteryzuje się on wieloma niekorzystnymi wskaźnikami w porównaniu do ich średniej wielkości w sektorze bankowym państw UE. Opracowanie zakończono wnioskami i udzielono odpowiedzi na postawione pytania badawcze. 